\title{
Comparative Study of Two Spectrophotometric Reagents for Catechol Analysis in Guaraná Seeds Powder
}

\author{
Adriana Magna, Acácia A. Salomão, Marta M. D. C. Vila and Matthieu Tubino* \\ Instituto de Química, Universidade Estadual de Campinas, CP 6154, 13084-971 Campinas - SP, Brazil
}

\begin{abstract}
Neste trabalho são descritos e comparados dois métodos espectrofotométricos para análise de catecol (o-hidroxifenol) em Paullinea cupana var. sorbilis, popularmente conhecido como guaraná. As amostras de sementes trituradas foram extraídas com etanol $97 \%$ v/v e as soluções tratadas com $p$-aminofenol em meio etanólico alcalino ou $m$-aminofenol e metaperiodato de sódio em solução tampão (pH 3.0). A absorbância foi medida a $586 \mathrm{~nm}$ e $520 \mathrm{~nm}$ respectivamente. Quatro produtos comerciais diferentes foram analisados e os resultados foram comparados com aqueles obtidos com $m$-aminofenol. Apesar da boa qualidade das curvas de calibração, nos dois métodos houve interferência da matriz, o que foi contornado usando-se o método da adição de padrão. A comparação entre os resultados obtidos pelos dois métodos, usando o teste estatístico $t$ de Student, mostrou que não há diferenças significantes para um nível de confiança de $95 \%$.
\end{abstract}

In this article are described and compared two spectrophotometric methods for the analysis of catechol (o-hydroxyphenol) in Paullinea cupana var. sorbilis, popularly known as guaraná. The pounded seed samples were extracted with ethanol $97 \% \mathrm{v} / \mathrm{v}$ and the solutions were treated with $p$-aminophenol in alkaline ethanolic medium or $m$-aminophenol and sodium metaperiodate in buffered aqueous solution (pH 3.0). The absorbance was measured at $586 \mathrm{~nm}$ and $520 \mathrm{~nm}$ respectively. Four different commercial products were analyzed and the results were compared with those obtained with the $m$-aminophenol method. Despite the good quality of the calibration curves, in the two methods the interference of the matrix was observed. This problem was settled using the standard addition method. Comparison between the results obtained by the two methods, using the statistical Student's $t$-test, showed that there is no significant difference at the $95 \%$ confidence level.

Keywords: guaraná, catechol, spectrophotometry, aminophenol

\section{Introduction}

The "guaranazeiro", Paullinea cupana var. sorbilis, is a climbing shrub plant native in the Amazonic region. It is known for its medicinal value but is also very popular in the form of a refreshing and pleasant soft drink in Brazil. The guaraná possess a great number of medicinal properties and is considered one of the most precious manifestations of the Brazilian flora. Among such properties includes its stimulant effect, anti-thermal, anti-neuralgic, antidiarrheic, analgesic and anti-grippe actions. ${ }^{1}$ Historically, the guaraná is used from the pre-Columbian period. Several tribes of Indians, like Andirás, Maués, Marabitanas, among many others used as a beverage prepared with the seed. ${ }^{2}$

The first botanic registers of the guaraná plant are of the XVIII century, when the naturalists Humbold and Bomblandt observed the plant in Colombia and in Venezuela. The

*e-mail: tubino@iqm.unicamp.br scientific gender name of the plant, Paullinea, is homage to the German botanic C.F. Paullini. The specimens name, cupana, was taken from popular Colombian word for this plant. In 1826, Martius observed some botanic differences between the plants collected in the low Amazons, Maués region in Brazil, and those collected in the high Rio Negro and Orenoco, Colombia and Venezuela. In 1935 this differences were confirmed by Ducke that distinguished the variety Paullinea cupana var. cupana, from Colombia and Venezuela, and the variety Paullinea sorbilis var. cupana, from Brazil. The variety cupana does not have commercial value but the sorbilis is cultivated in large scale in Brazil, mainly in Maués, Amazon State. , $^{3,4}$

The Brazilian "guaraná amends" production is $70 \%$ which is used in the preparation of soft drinks. $15 \%$ are industrialized in the stick form. The other $15 \%$ are produced as powder, extract and syrup that are sold in the Brazilian market where it finds popular uses. It is also exported or sold to the pharmaceutical industry. 
The Brazilian Decree number 73267, established minimum and maximum quantities of guaraná in the soft drinks that present such a designation. Each $100 \mathrm{~mL}$ of the beverage must contain a minimum of $0.02 \mathrm{~g}$ and a maximum of $0.2 \mathrm{~g}$ of guaraná seed, or its equivalent in syrup. However, if the Brazilian production of guaraná seeds is compared with the production of the soft drink, a doubt appears about the respect to the cited Decree. ${ }^{2}$

Other products can be produced from the guaraná. For example: decaffeinated guaraná, caffeine, guaraná soluble. ${ }^{4}$ In United States, it is used as a natural flavoring for soda beverages, as stimulant, as food supplement in the form of capsules that contain 800-1200 mg of guaraná seeds powder. It can be also associated to other herbs. ${ }^{5}$

From the years sixties, began an effort to increase production and to find new uses and to ensure control quality. ${ }^{6}$ However, relatively little is known about its chemical composition, fact those easeas falsifications. There are no many options of analytical techniques for the identification and evaluation of the commercial product. A study done with commercial products showed a high content of cinder, suggesting adulteration with inorganic products and either ground. ${ }^{7}$

Usually the control of the quality of the guaraná products is done dosing caffeine, which is present in the natural product complexes with tannins. Considering that kind of analytical control and the low price of caffeine, it is easy to understand that is very cheap and very easy to falsify guaraná. Several analytical procedures for the analysis of caffeine can be used. For example: paper chromatography, ${ }^{8}$ liquid chromatography ${ }^{5}$ and high efficiency liquid chromatography. ${ }^{9}$ However, these procedures are relatively very laborious and the results are not satisfactory. ${ }^{9}$ Therefore the determination of other chemical species, than caffeine, in the guaraná, would allow a more efficient control of the commercial products. One alternative to analyzing caffeine in guaraná is to determine the content of polyphenols like catechol. ${ }^{10}$

Aiming to contribute with simple and easy analytical methods to be used for the guaraná quality control, in this work two spectrophotometric quantitative analytical methods for catechol analysis were adapted and applied for the determination of this compound in guaraná seeds powder.

\section{Experimental}

\section{Apparatus}

A single beam UV-visible spectrophotometer Pharmacia Biotech Model Ultrospec 2000, coupled to a PC like computer was used for the absorbance measurements.
Reagents and solutions

All the reagents used were of analytical grade. The water used to prepare the solutions was distilled in a glass distiller and deionized in a QMilli Plus deionizer.

The catechol (Fluka Chemicals) standard solutions $\left(1.00 \times 10^{-2} \mathrm{~mol} \mathrm{~L}^{-1}\right)$ was prepared by dissolving $0.0110 \mathrm{~g}$ of catechol in a $100.0 \mathrm{~mL}$ volumetric flask with ethanol $97 \% \mathrm{v} / \mathrm{v}$ to complete the volume. This solution was used in the method with $p$-aminophenol. The catechol solution $\left(1.00 \times 10^{-3} \mathrm{~mol} \mathrm{~L}^{-1}\right)$ was prepared by dissolving $0.110 \mathrm{~g}$ of catechol were dissolved in a $100.0 \mathrm{~mL}$ volumetric flask with water enough to complete the volume. This solution was used in the method with $m$-aminophenol.

The $p$-aminophenol (Fluka Chemicals) solution (1.0 $\times 10^{-3} \mathrm{~mol} \mathrm{~L}^{-1}$ ) was prepared by dissolving $0.0109 \mathrm{~g}$ in $100.0 \mathrm{~mL}$ of $\mathrm{HCl} 0.1 \mathrm{~mol} \mathrm{~L}^{-1}$ aqueous solution. The $m$ aminophenol (Fluka Chemicals) solution $\left(2.0 \times 10^{-2} \mathrm{~mol} \mathrm{~L}^{-1}\right)$ was prepared dissolving $0.218 \mathrm{~g}$ in a $100.0 \mathrm{~mL}$ volumetric flask with the buffer $(\mathrm{pH} 3.0)$ to complete the volume.

The sodium hydroxide solution $(2 \% \mathrm{~m} / \mathrm{v})$ was prepared by dissolving $20 \mathrm{~g}$ in water, completing the volume to 1.0 liter. The $\mathrm{HCl}$ solution $\left(0.1 \mathrm{~mol} \mathrm{~L}^{-1}\right)$ aqueous solution was prepared by diluting $8.5 \mathrm{~mL}$ of a concentrated solution $(36.5 \% \mathrm{~m} / \mathrm{v})$ up to 1.0 liter with water. The buffer solution ( $\mathrm{pH}$ 3.0) was prepared with $125 \mathrm{~mL}$ of an aqueous solution of potassium biphthalate $0.1 \mathrm{~mol} \mathrm{~L}^{-1}$ and $51 \mathrm{~mL}$ of the aqueous solution of $\mathrm{HCl} 0.1 \mathrm{~mol} \mathrm{~L}^{-1}$ were mixed in a 250.0 $\mathrm{mL}$ volumetric flask and the volume was completed with water.

The sodium metaperiodate $\left(\mathrm{NaIO}_{4}\right)$ (Sigma) solution $\left(1.0 \times 10^{-2} \mathrm{~mol} \mathrm{~L}^{-1}\right)$ solution was prepared by dissolving $2.14 \mathrm{~g}$ in of the salt in water completing the volume to 1.0 liter. And the potassium biphthalate (Fluka Chemicals) solution $\left(0.1 \mathrm{~mol} \mathrm{~L}^{-1}\right)$ solution was prepared by dissolving $20.4 \mathrm{~g}$ of the salt with water to complete 1.0 liter.

The guaraná powder samples of four different trade marks were purchased in the local market.

\section{Calibration curves}

p-aminophenol method. ${ }^{11}$ Calibration curve was prepared using $0.0,10.0,25.0,50.0,75.0$ and $100.0 \mu \mathrm{L}$ of catechol standard solution $\left(1.0 \times 10^{-2} \mathrm{~mol} \mathrm{~L}^{-1}\right.$ in ethanol), separately, in five $10.0 \mathrm{~mL}$ volumetric flasks containing also $3.0 \mathrm{~mL}$ of the $2 \% \mathrm{~m} / \mathrm{v} \mathrm{NaOH}$ solution and $3.0 \mathrm{~mL}$ of $p$-aminophenol solution $\left(1.0 \times 10^{-3} \mathrm{~mol} \mathrm{~L}^{-1}\right)$. The volume was completed with ethanol. The addition order was: $\mathrm{NaOH}$ solution, $p$-aminophenol, and catechol. The absorbance was measured in $586 \mathrm{~nm}, 1$ minute after the addition of the catechol. 
m-aminophenol method. ${ }^{12}$ In five $25.0 \mathrm{~mL}$ volumetric flasks were added in each one, in the following order: $15.0 \mathrm{~mL}$ of the buffer solution $(\mathrm{pH}=3.0) ; 1.0 \mathrm{~mL}$ of the $m$ aminophenol solution $\left(2.0 \times 10^{-2} \mathrm{~mol} \mathrm{~L}^{-1}\right) ; 2.0 \mathrm{~mL}$ of the sodium metaperiodate solution $\left(1.0 \times 10^{-2} \mathrm{~mol} \mathrm{~L}^{-1}\right)$. Then it was added separately, in the five volumetric flasks, 0.5 , $1.0,2.0,3.0$ and $4.0 \mathrm{~mL}$, of the aqueous catechol solution $\left(1.0 \times 10^{-3} \mathrm{~mol} \mathrm{~L}^{-1}\right)$. The volume was completed to $25.0 \mathrm{~mL}$ with water. The absorbance was measured in 520 $\mathrm{nm}$, one minute after the addition of the catechol.

\section{Analytical procedure}

Considering the interference of the matrix, the standard addition method was adopted as the analytical procedure.

p-aminophenol method. One aliquot of about $1.0 \mathrm{~g}$ of each sample of the powder of guaraná was exactly weighed to $0.1 \mathrm{mg}$ and mixed to $100.0 \mathrm{~mL}$ of ethanol. The mixture was allowed to macerate overnight at room temperature (about $25{ }^{\circ} \mathrm{C}$ ). Then it was filtered through quantitative filter paper. To five $10.0 \mathrm{~mL}$ volumetric flasks were added $3.0 \mathrm{~mL}$ of the $2 \% \mathrm{~m} / \mathrm{v} \mathrm{NaOH}$ solution and $3.0 \mathrm{~mL}$ of the $p$ aminophenol. Then it was added $1.00 \mathrm{~mL}$ of the guaraná extract and the adequate catechol standard solution volume, $0.0,10.0,25.0,50.0,75.0$ and $100.0 \mathrm{~mL}$. The volume was completed with ethanol. The absorbance was measured in $586 \mathrm{~nm}$ about 1 minute after the addition of the catechol.

m-aminophenol method. One aliquot of about $1.0 \mathrm{~g}$ of each sample of the powder of guaraná was exactly weighed to $0.1 \mathrm{mg}$ and mixed to $100.0 \mu \mathrm{L}$ of ethanol. The mixture was allowed to macerate overnight at room temperature (about $25^{\circ} \mathrm{C}$ ). To five $25.0 \mathrm{~mL}$ volumetric flasks were added, in the following order: $15.0 \mathrm{~mL}$ of the buffer solution (pH 3.0); $1.0 \mathrm{~mL}$ of the $m$-aminophenol solution $\left(2.0 \times 10^{-2} \mathrm{~mol} \mathrm{~L}^{-1}\right) ; 2.0 \mathrm{~mL}$ of the sodium metaperiodate solution $\left(1.0 \times 10^{-2} \mathrm{~mol} \mathrm{~L}^{-1}\right) ; 4.0 \mathrm{~mL}$ of the guaraná extract; $0.5,1.0,2.0,3.0$ and $4.0 \mathrm{~mL}$, separately in the five volumetric flasks, of the aqueous catechol solution $(1.0 \times$ $\left.10^{-3} \mathrm{~mol} \mathrm{~L}^{-1}\right)$. The volume was completed to $25.0 \mathrm{~mL}$ with water. The absorbance was measured in $520 \mathrm{~nm}$, one minute after the addition of the catechol.

\section{Results and Discussion}

The reactions of $p$-aminophenol and $m$-aminophenol with catechol form indophenol dye like species. ${ }^{13}$ In Figure 1 can be observed the spectra of the product obtained through the reaction of the catechol (a) and of the guaraná extract (b) with the $p$-aminophenol. The specific molar absorbance in the maximum absorbance $(\lambda=586 \mathrm{~nm}$;

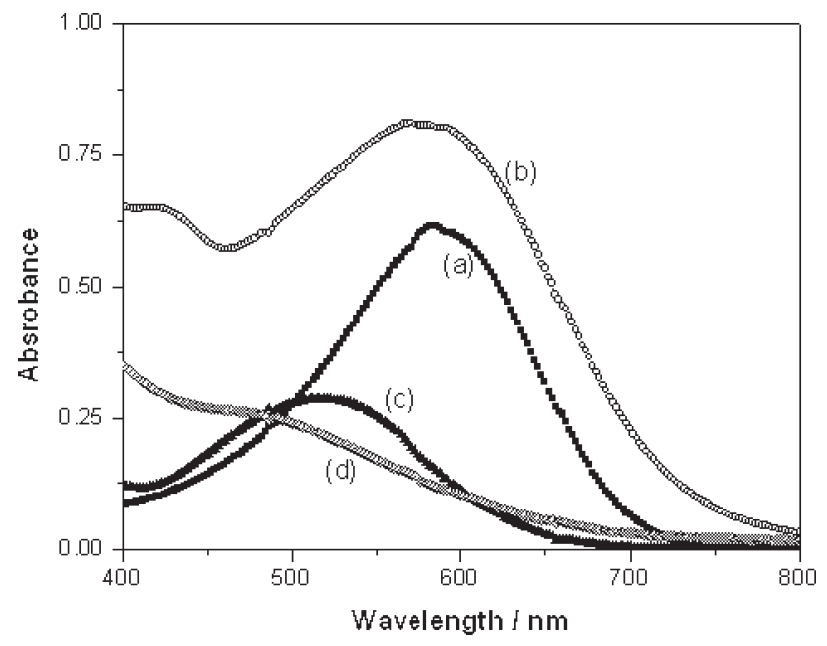

Figure 1. Absorption spectra of ethanol solutions of: (a) catechol $\left(5.0 \times 10^{-5} \mathrm{~mol} \mathrm{~L}^{-1}\right)$ with $p$-aminophenol and $\mathrm{NaOH}$; (b) guaraná extract $\left(5.0 \times 10^{-5} \mathrm{~mol} \mathrm{~L}-1\right.$, content of catechol $) . \lambda_{\max }=586 \mathrm{~nm} ; \varepsilon=$ $1.3 \times 10^{4} \mathrm{~L} \mathrm{~mol}^{-1} \mathrm{~cm}^{-1}$. Absorption spectra of the aqueous solutions of: (c) catechol $\left(5.0 \times 10^{-5} \mathrm{~mol} \mathrm{~L}^{-1}\right)$ with $m$-aminophenol and metaperiodate in $\mathrm{pH} 3.0$; (d) guaraná extract $\left(5.0 \times 10^{-5} \mathrm{~mol} \mathrm{~L}^{-1}\right.$, content of catechol). $\lambda_{\max }=520 \mathrm{~nm} ; \varepsilon=5.7 \times 10^{3} \mathrm{~L} \mathrm{~mol}^{-1} \mathrm{~cm}^{-1}$.

blue ) is $\varepsilon=1.3 \times 10^{4} \mathrm{~L} \mathrm{~mol}^{-1} \mathrm{~cm}^{-1}$. It can be also observed the spectra of the product obtained through the reaction of the catechol (c) and of the guaraná extract (d) with the $m$ aminophenol. The specific molar absorbance in the maximum absorbance $(\lambda=520 \mathrm{~nm}$; reddish) is $\varepsilon=5.7 \times$ $10^{3} \mathrm{~L} \mathrm{~mol}^{-1} \mathrm{~cm}^{-1}$. Comparing the two molar absorptivities it is expected that the $p$-aminophenol method will present a detection limit about the double of the $m$-aminophenol method, as observed.

The two tested analytical procedures furnished very good linear calibration graphs. For the $p$-aminophenol method, the curve absorbance versus concentration is described by the equation $\mathrm{A}=1.52 \times 10^{-2}+1.27 \times 10^{4} \times \mathrm{C}$ $\left(R^{2}=0.9999\right)$. The detection limit is estimated as about 3.8 $\times 10^{-6} \mathrm{~mol} \mathrm{~L}^{-1}$ and it was calculated on the basis of the observed absolute standard deviation of the lower concentration of catechol used to construct the calibration curve $(3 \times \mathrm{SD})$. The mean of the relative standard deviation was about $6.3 \%$. For the $m$-aminophenol procedure, the calibration curve is described by the equation $\mathrm{A}=7.74 \times$ $10^{-3}+5.67 \times 10^{3} \mathrm{C}\left(\mathrm{R}^{2}=0.9986\right)$. The detection limit, calculated as above was observed to be $7.3 \times 10^{-6} \mathrm{~mol} \mathrm{~L}^{-1}$ and the mean relative standard deviation is about $3.8 \%$. In all cases $\mathrm{A}$ means absorbance and $\mathrm{C}$ is the catechol concentration in mol L-1. Despite the very good linearity of the calibration curves in the two methods, the direct determination of catechol in guaraná can't be performed as interference of the matrix is observed. The two methods gave, between them, non-concordant values. For instance, 
for the guaraná sample number 1 , whereas the $p$-aminophenol method furnished the value $8.76 \pm 0.30 \mathrm{mg} \mathrm{g}^{-1}$, the $m$-aminophenol method gave $5.16 \pm 0.19 \mathrm{mg} \mathrm{g}^{-1}$. Eight determinations were performed in each case $(n=8)$. When the standard addition procedure was applied to the two methods, $7.96 \pm 0.15 \mathrm{mg} \mathrm{g}^{-1}(\mathrm{n}=4)$ and $8.05 \pm 0.25 \mathrm{mg} \mathrm{g}^{-1}$ $(\mathrm{n}=4)$ were found for the $p$-aminophenol and for the $m$-aminophenol methods respectively. Observing the spectra in Figure 1 it is easy to note the matrix influence. For the same catechol content, for the $p$-aminophenol method the spectrum (b) resulted from the guaraná matrix is more intense than that resulted from the catechol alone. The contrary is observed for the $m$-aminophenol method, at $520 \mathrm{~nm}$, where the spectrum (d) from the guaraná matrix is less intense that obtained from the catechol alone. Therefore the standard addition procedure was adopted. The analytical curves for the standard addition procedure are described by straight lines with very good correlation coefficients: $\mathrm{R}^{2}=0.9986$ $(\mathrm{A}=0.548+5.22 \mathrm{C})$ for the $m$-aminophenol method and $\mathrm{R}^{2}=0.9995(\mathrm{~A}=0.718+9.94 \mathrm{C})$ for the $p$-aminophenol method. In Table 1, can be seeing the results obtained for the four real samples analyzed.

Table 1. Quantitative analysis of catechol in guaraná samples. Values under $p$ correspond to the $p$-aminophenol method and those under $m$ to the $m$-aminophenol method.

\begin{tabular}{cccc}
\hline $\begin{array}{c}\text { Sample } \\
\text { Number }\end{array}$ & $\begin{array}{c}p^{a} \\
\left(\mathrm{mg} \mathrm{g}^{-1}\right) \pm \mathrm{s}\end{array}$ & $\begin{array}{c}m^{a} \\
\left(\mathrm{mg} \mathrm{g}^{-1}\right) \pm \mathrm{s}\end{array}$ & $\begin{array}{c}\text { Student's } \\
t-\text { value }^{b}\end{array}$ \\
\hline 1 & $7.96 \pm 0.15$ & $8.05 \pm 0.25$ & 0.29 \\
2 & $3.28 \pm 0.62$ & $3.73 \pm 0.10$ & 1.60 \\
3 & $1.32 \pm 0.03$ & $1.31 \pm 0.02$ & 0.62 \\
4 & $5.55 \pm 0.48$ & $5.36 \pm 0.44$ & 0.58 \\
\hline
\end{tabular}

a Average values of four determinations \pm the estimate of the standard deviation (s); ${ }^{\mathrm{b}}$ The tabulated $t$-value at 0.05 confidence level is 2.45 , for the degree of freedom (n) equal to $6\left(n=n_{1}+n_{2}-2\right)$.

\section{Conclusions}

As it can be observed the results furnished by the two methods agree very well in a confidence level of $95 \%$, indicating that the catechol concentrations determined in the powder of guaraná correspond to the real content with a high degree of probability. Values between 0.34 and 32 $\mathrm{mg} \mathrm{g}^{-1}$ are related in commercial products. ${ }^{5}$
Based on the obtained values, both methods can be suggested for the analysis. However that using $p$ aminophenol presents a more simple procedure and the use of sodium metaperiodate is not necessary.

\section{Acknowledgments}

The authors are grateful to Fundação de Amparo à Pesquisa do Estado de São Paulo, FAPESP, and Conselho Nacional de Desenvolvimento Científico e Tecnológico, $\mathrm{CNPq}$, for financial support.

\section{References}

1. Dewick, P. M; Medicinal Natural Products - A Biosynthetic Approach, $1^{\text {st }}$ ed., John Wiley \& Sons: Chichester, England, 1998, p. 369.

2. Corrêa, M.P.; Dicionário das Plantas Úteis do Brasil e das Exóticas Cultivadas, Imprensa Nacional: Rio de Janeiro, 1984, vol. 3, p. 545.

3. Castro, N.H.C.; A Cultura do Guaranazeiro, Empresa Brasileira de Pesquisa Agropecuária, EMBRAPA: Belém, 1992.

4. Poltrieri, M.C.; Duarte, M.L.; Rodrigues, J.E.; Nazaré, R.F.R.; Kato, A.K.; Oliveira, A.F.F.; A Cultura de Guaraná, EMBRAPA: Brasília, 1996.

5. Carlson, M.; Thompsom, R.D.; J. AOAC Inter. 1989, 81, 691.

6. Corrêa, M.P.F.; Garcia, T.B.; Boletim SBCTA 1989, 23, 90.

7. Pereira, E.A.; Alves, S.M.; Grandi, T.S.M.; Campos, L.M.M.; Brandão, M.G.L.; Infarma 1999, 12, 76.

8. Costa, A.F.; Farmacognosia, Fundação Calouste Gulbekian: Lisboa., 1972, vol. 3, p. 898

9. Marx, F.; Maia, J.G.; Quim. Nova 1990, 13, 285.

10. Bruneton, J. ; Pharmacognosie - Phytochimie Plantes Medicinales, $2^{\text {nd }}$ ed., Lavoisier Technique et Documentation: Paris, 1993 , p. 892.

11. Chubb, S.A.P.; Campbell, R.S; Ramsay, J.R.; Hammond, P.M;. Atkison, T.; Price, C.P.; Clin. Chim. Acta 1986, 155, 209.

12. Sastry, C.S.P.; Rao, K.E.; Prasad, U.V.; Talanta 1982, $29,917$.

13. Criado, A; Cárdenas, S.; Gallego, M.; Valcárcel, M.; Analyst 2000, 125, 1179.

Received: March 25, 2002

Published on the web: December 13, 2002

FAPESP helped in meeting the publication costs of this article. 